\title{
Hybritech wins court injunction over sandwich assays
}

\section{Washington}

THE US biotechnology company Hybritech has scored yet another coup in defence of its much-contested patent for sandwich assays. A US judge is to issue a preliminary injunction forcing Abbott Laboratories to suspend sales of products using the sandwich assay technique.

Hybritech filed suit against Abbott last December, charging that some of Abbott's diagnostic tests infringed its patent for sandwich assays. The technique uses two monoclonal antibodies to make an antibody-antigen-antibody 'sandwich' which can detect small quantities of antigen for the early diagnosis of disease or pregnancy.

The preliminary injunction will affect several of Abbott's diagnostic tests for thyroid disorders, cancer and pregnancy. While these tests currently comprise only 7 per cent of Abbott's total diagnostic sales, if a permanent injunction results from the coming trial, it could freeze Abbott out of the potential $\$ 5,000$ million market for the diagnostic tests. The date for the trial has not yet been set.

The sandwich assay patent has been surrounded in dispute since Hybritech first sued Monoclonal Antibodies, Inc. for infringement in 1984. Hybritech lost the case, and its patent, on the ruling that the technique was obvious to anyone skilled in the field. Hybritech appealed, and its patent was restored a year later under a more liberal interpretation of the evidence presented in Hybritech's laboratory notes to demonstrate its conception date.

Hybritech then re-entered its patent infringement suit against Monoclonal Antibodies, Inc. A preliminary injunction against Monoclonal Antibodies was announced a month ago, but has not yet been issued. Monoclonal Antibodies has more to lose than Abbott, because sandwhich assays make up about 80 per cent of the company's product sales.

New evidence has come to light that may reopen the question of the validity of the Hybritech patent, however. The attorney for Abbott Laboratories, Robert Benson, has recruited a witness who claims to have discussed the sandwich assay technique at a conference in Seattle, Washington, in March 1979 - over a year before Hybritech applied for a patent. But the Hybritech conception date - the date from which the patent is active - was established in the previous trials as 4 January 1979. If this stands, Abbott's new witness may not be able to bail them out.

\section{European disunity}

IN an effort to end the current deadlock over its $\mathfrak{£ 4 , 5 8 0}$ million high-technology research programme, the European Communities Commission is considering asking Britain to withdraw from all EEC research projects. Britain has been opposing the five-year research project, which is agreed by all other EEC governments, on the grounds that it is unfocused and poorly monitored. Unanimous agreement is essential if the programme is to go ahead, but if Britain decides not to participate the other 11 countries could proceed with what they see as an essential European response to US and Japanese high-tech research.

A formal request to Britain to withdraw voluntarily would be without precedent. But the British position has been strongly criticized by other EEC countries, and there have been warnings that some research teams may have to be disbanded if the stalemate is not resolved soon. British opposition to the research programme is thought to come partly from government departments; under Treasury rules, the cost of EEC research can be deducted from a ministry's budget.

K.J.

\section{Shuttle stays earthbound}

The National Aeronautics and Space Administration (NASA) has abandoned plans to resume shuttle launches by 18 February 1988 following a decision by NASA to add two new tests before launching. NASA spokesman Jim Ball says the tests are not only important for the information they will give engineers about modifications to the shuttle, but will also give ground technicians a chance to try out new pre-launch procedures. NASA has made numerous modifications to the shuttle - some arising from investigations into the Challenger accident. Brakes, landing gear, main engines and the solid rocket motor have all been modified.

NASA estimates that there will be a 6 to 8 week delay to perform the fuelling and test firing tests. New launches are unlikely before the second half of next year.

J.P.

\section{AIDS committee}

THE Soviet Ministry of Health has proposed the establishment of an international coordinating committee for research on AIDS. Speaking on Moscow television, Dr Evgenii Chazov, the All-Union Health Minister, said the issue had already been raised with the World Health Organization (WHO), and that the Soviet delegation to the WHO General Assembly in May hopes to discuss it more fully. The proposed committee, Chazov said, would coordinate investigations into the nature of AIDS, diag. nosis, the development of vaccines, and also preventative measures. International efforts would be important, Chazov said, in studying AIDS epidemiology. V.R. towards lower energies both in the United States and in West Germany, embodied in
Paola De Paoli 